\title{
14. Franciaország: folyamatosan különleges jogrend, a koronavírus idején is
}

\author{
STOLLSTEINER GABRIEL
}

\section{A különleges jogrend szabályozása és esetkörei}

Viharos 19. és 20. századi történelméből következően Franciaország különböző különleges jogrendre vonatkozó szabályokkal rendelkezik. Minden egyes különleges jogrend olyan körülményeknek köszönheti a megjelenését, amelyek esetében szükségesnek ítélték alkalmazását. Ennek eredményeként a kivételes rendszerek mind forrásukban, mind alkalmazásukban eltérnek. Más országokkal ellentétben, ahol az alkotmány a különleges jogrendek minden esetét szabályozza, a francia rendszer a különböző szintú - különböző helyzetek kezelésére szolgáló - szabályok egymás mellé rendelésének következménye.

A 2015-ös terrortámadásokat követően felvetődött a különleges jogrend meghatározásának kérdése. A vita a 2000-es évek elején kezdődött a szeptember 11-i támadásokat követően: a szükségállapot két fogalma szembesül egymással. Első, klasszikus értelemben a különleges jogrenden azt az időszakot értjük, amely alatt a békés időszakokra előírt törvényi szabályokat a veszély függvényében átlépik, felfüggesztik vagy félreteszik. ${ }^{1}$ Ebben az időszakban egyrészt a hatalom koncentrációja zajlik, általában a végrehajtó hatalom

1 Saint-Bonnet, 2008, 30. o.

Stollsteiner Gabriel

gabriel.stollsteiner@mfi.gov.hu

PhD-hallgató, tanársegéd (Université Paris-Est Créteil)

kutató (Mádl Ferenc Összehasonlító Jogi Intézet)

Stollsteiner, G. (2021) 'Franciaország: folyamatosan különleges jogrend, a koronavírus idején is’ in Nagy, Z., Horváth, A. (szerk.) A különleges jogrend és nemzeti szabályozási modelljei, 322-340. o. Budapest: Mádl Ferenc Összehasonlító Jogi Intézet.

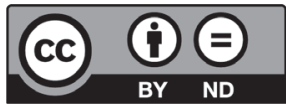

https://doi.org/10.47079/2021.nzha.kulon.4_14 
javára, másrészt pedig a béke idején alapvetőnek tekintett jogok korlátozása vagy felfüggesztése. E meghatározás szerint egy adott veszéllyel való szembenézés érdekében létrejövő ideiglenes időszakról van szó. A közelmúltban keletkezett második jelentésében a szükségállapot bizonyos jogrendszerek mélyreható átalakításából áll: olyan tartós veszélyek ellen, mint például a terrorizmus. ${ }^{2}$ A módosítások azért mélyrehatóak, mert a szabályok a hatályban lévő politikai és jogi rendszerre jellemzővé válnak. Ebben a helyzetben az ideiglenesnek hirdetett kivételes jogrend tartóssá válhat, és az állam múködésében „a kivétel lesz a normális”. ${ }^{3}$ Ebben a fejezetben a különleges jogrend az első meghatározásra utal, amely valóban kivételt képez az úgynevezett „normális” jogrend alól. Ez a tanulmány a francia különleges jogrendszerre összpontosít, és nem foglalkozik az úgynevezett „állandósult kivételesség” kérdésével, amelynek hatása mégis fontos. ${ }^{4}$

A francia jogrendben a különleges jogrend nevesített esetkörei a következők: ostromállapot, rendkívüli elnöki jogkör és szükségállapot. A szövegek által elöírt jogrendekhez társul hasonló céllal a „kivételes körülmények” bírósági gyakorlata. Az egyértelmúség kedvéért a kivételes rendszereket a normahierarchiában elfoglalt rangjuk szerint mutatjuk be, amely nagymértékben megfelel a megjelenésük időrendjének.

\subsection{Az ostromállapot}

Az ostromállapot (état de siège) a legrégibb olyan különleges jogrend, amelyet a konfliktus jellegú helyzetekre alkalmaznak: súlyos zavargások az ország területén, polgárháború vagy megszállás. Ahogy a neve is mutatja, az eredeti, 1791-es törvény az ostromlott erődök védelmének megszervezését tûzte ki célul, ${ }^{5}$ ezért engedélyezte a rendőri hatáskörök átadását a polgári hatóságtól a katonai hatóságnak. A későbbi törvények pedig a katonai bíróságok létrehozását és a rendőri hatáskörök kiterjesztését engedélyezték. ${ }^{6}$ Eközben megjelenik a politikai ostromállapot ${ }^{7}$ fogalma, amely eltér a katonai értelemben vett ostromállapottól. Az ostromállapot hatályának kiterjesztése tehát együtt járt a pontosabb jogi kerettel.

Az V. köztársaság 1958. október 4-én elfogadott alkotmánya ${ }^{8}$ értelmében az ostromállapotot minisztertanácsi rendelet hirdeti ki, 12 napon túli meghosszabbításáról pedig kizá-

2 Bővebben lásd: Agamben, 2005.

3 Ságvári, 2017.

4 A szükségállapotra vonatkozó rendelkezéseknek az általános jogba történő átültetését az alábbiakban tárgyaljuk; a globális biztonságról és szeparatizmusról szóló törvényjavaslatokat, amelyek a sajtószabadságot és a magánélet tiszteletben tartását érintik, azonban nem.

5 1791. július 10-i törvény (Loi du 10 juillet 1791 concernant la conservation et le classement des places de guerre et postes militaires, la police des fortifications et autres objets y relatifs).

6 1849. augusztus 9-i törvény az ostromállapotról, 1878. április 3-i törvény az ostromállapotról (Loi du 9 août 1849 sur l'état de siège; Loi du 3 avril 1878 relative à l'état de siège).

7 Manin, 2015.

8 Constitution française du 4 octobre 1958 (a továbbiakban: alkotmány). 
rólag a parlament dönthet. ${ }^{9}$ A rendelet kijelöli azt a területet, amelyre vonatkozik, és meghatározza alkalmazásának időtartamát. A 2005-ben elfogadott honvédelmi törvénykönyv ${ }^{10}$ pedig előírja, hogy az ostromállapot elrendelésére külső támadás vagy fegyveres felkelés közvetlen veszélye esetén kerülhet sor. ${ }^{11}$

Bizonyos jogok gyakorlását felfüggesztik: ilyen a magánlakás sérthetetlensége, a sajtószabadság, a gyülekezési szabadság és a mozgásszabadság. A katonai hatóságnak joga van kijárási tilalom kiírására, nappali és éjszakai házkutatásra az állampolgárok otthonában, fegyverek és lőszerek átadásának elrendelésére, felkutatására és eltávolítására, illetve a rendbontásra felbujtó vagy fenntartó publikációk és találkozók megtiltására. A katonai bíróságok hatáskörébe tartoznak az állambiztonság elleni büncselekmények. ${ }^{12}$

Összességében a politikai és katonai körülmények alakulásával - az aszimmetrikus hadviseléssel - ez a különleges jogrend elavulttá vált. Helyette a polgári megfelelőjét, a szükségállapotot használják, amelyről később lesz szó.

\subsection{A rendkiviüli elnöki jogkör}

A rendkívüli elnöki jogkör (pouvoirs exceptionnels) az V. köztársaság alkotmányának szövegében jelenik meg először. ${ }^{13}$ Amikor a köztársaság intézményei, a nemzeti függetlenség vagy a területi integritás, esetleg amikor az ország nemzetközi kötelezettségvállalásainak teljesítése súlyos és közvetlen veszélyben van, és az alkotmányos intézmények rendes múködése nem biztosított, az elnök megteszi a szükséges intézkedéseket, miután egyeztetett a miniszterelnökkel, a parlament két házának elnökével és az Alkotmánytanáccsal. ${ }^{14}$ Errôl az elnök hivatalosan tájékoztatja a nemzetet. ${ }^{15} \mathrm{Az}$ elnök gyakorlatilag teljes hatáskörrel rendelkezik az intézmények rendszeres müködésének gyors helyreállításához szükséges intézkedések megtételére - az Alkotmánytanács erről véleményt ad. ${ }^{16}$ E különleges jogrend ideje alatt a parlament továbbra is ülésezik; az első kamaraként szolgáló Nemzetgyúlés nem oszlatható fel. ${ }^{17}$ A 2008-ban elfogadott alkotmánymódosítás határidôket szabott a rendkívüli jogkör gyakorlására: az intézkedések megkezdése után 30 nappal az Alkotmánytanács megvizsgálhatja, hogy a fent meghatározott feltételek to-

\footnotetext{
9 Alkotmány 36. cikk.

10 Code de la défense (a továbbiakban: Honvédelmi tv.).

11 Honvédelmi tv. L2121-1 cikk.

12 Honvédelmi tv. L2121-3 cikk.

13 Alkotmány 16. cikk.

14 Alkotmány 16. cikk (1) bekezdés.

15 Alkotmány 16. cikk (2) bekezdés.

16 Alkotmány 16. cikk (3) bekezdés.

17 Alkotmány 16. cikk (4)-(5) bekezdés.
} 
vábbra is teljesülnek-e. ${ }^{18} 60$ nap elnöki jogkörgyakorlás után az Alkotmánytanács hivatalból köteles a kérdést megvizsgálni.

A rendkívüli elnöki jogkör eredetileg az 1958-ban megszavazott teljhatalom alkotmányossá tételét jelentette. ${ }^{19} \mathrm{~A}$ teljhatalmat elsősorban az algériai zavargások megszüntetése érdekében szavazták meg a IV. köztársaság összeomlása során. Ez szorosan összefügg a dekolonizáció folyamatával és különösen az algériai eseményekkel. Az Algériában szimpatizánsai által szervezett katonai felkelés során az addig politikailag visszavonult De Gaulle-t a parlament teljes jogkörrel szavazta meg. Ez hasonló körülmények közt történt, mint amikor az 1940. július 11-én, a Vichyben összehívott nemzetgyứlés teljhatalommal ruházta fel Pétaint. A módozatai azonban különböznek, ugyanis az 1958-as teljhatalom hat hónapra szólt. Ebből kiérződik az ókori római köztársasági diktatúra intézményének a sugallata, amikor is súlyos veszély esetén a szenátus kezdeményezésére és felhatalmazására az egyik konzult nevezték ki, általában hat hónapra (kezdetben egy katonai hadjárat idejére). ${ }^{20}$

Azt az állítást, miszerint az V. köztársaságot De Gaulle-ra szabták, közhelynek tekintik, ugyanakkor a 16. cikk esetében egyet kell értenünk abban, hogy a kivételes hatáskörök szorosan megfelelnek a De Gaulle-ra jellemző intézményi elképzeléseknek, napjainkban ezért is tartják anakronisztikusnak ezeket. ${ }^{21}$ Bár többször felmerült, eltávolítására eddig nem került sor. De Gaulle utódai föként az egyébként lenézett ${ }^{22}$ IV. köztársaságtól örökölt rendelkezést használták: a szükségállapotot.

\subsection{A szükségállapot}

A szükségállapotra (état d’urgence) vonatkozó jogszabályokat az algériai háború alkalmával hozták létre, és 1955 és 2015 között hatszor alkalmazták. ${ }^{23}$ Rendszere közel áll az ostromállapothoz, a fó különbség az, hogy az utóbbi a katonai hatóságot hatalmazza fel. A szükségállapotot a Minisztertanács rendeletben hirdeti ki a teljes államterületre vagy annak egy részére, az alábbi két esetben: egyrészt a közrend súlyos megsértéséből eredő közvetlen veszély esetén, másrészt olyan események bekövetkeztekor, amelyek természetüknél fogva és súlyosságukat tekintve közveszély előidézésére alkalmasak. Ennek a helyzetnek a tizenkét napon túl történő meghosszabbítását a törvény engedi, meghatározva annak végső időtartamát.

18 Ehhez a Nemzetgyưlés elnökének, a Szenátus elnökének, hatvan képviselőnek vagy hatvan szenátornak az indítványára van szükség [Alkotmány 16. cikk (6) bekezdés].

19 René Capitant (1901-1970) jogásznak tulajdonítják a jóindulatú értelmezést, amely szerint a 16. cikk emeli alkotmányos szintre az 1940. június 18-i De Gaulle-beszédet (amelyet a német megszállással szembeni ellenállás megalapozásának tekintenek) (Sirinelli, 1995, 842. o.).

20 Pierré-Caps, 2016.

21 Platon, 2008.

22 Garrigou, 2017.

23 Rendszerét az 1955. április 3-i törvény szabályozza, amelyet az 1960. április 15-i 60-372. sz. rendelet módosított, és a 2015. november 20-i 2015-1501. sz. törvény alaposan átdolgozott. 
A szükségállapot a következő esetekben ér véget:

— az azt kihirdető rendelet vagy törvény által előírt határidő lejártával;

- a kormány lemondását vagy a Nemzetgyúlés feloszlatását követően; vagy

- ha a meghosszabbítást engedélyező törvény előírja, hogy a szükségállapot minisztertanácsi rendelettel megszüntethető az előírt határidő lejárta előtt.

A szükségállapot kiterjeszti a polgári hatóságok hatáskörét, beleértve a kormány és a - területi szintû megbízottjainak tekinthető - prefektusok hatáskörét is. A belügyminiszter házi őrizetbe helyezheti azt a személyt, akinek tevékenységét a közbiztonságra és a közrendre veszélyesnek tekinti. Ez az intézkedés megtámadható egy bizottság előtt, és adott esetben a közigazgatási bíróság előtt, amelynek egy hónapon belül döntést kell hoznia. A 2015. november 20-i törvény módosította a házi őrizet rendszerét, kiterjesztve azt minden olyan személyre, akivel kapcsolatban „komoly okkal feltételezhető, hogy viselkedése veszélyezteti a közbiztonságot és a közrendet”. ${ }^{24} \mathrm{~A}$ belügyminiszter bármely, házi őrizetben lévő személy számára elöirhatja a rendőrség vagy a csendőrség egységei részére történő időszakos bejelentési (naponta legfeljebb háromszor) és személyazonosító okmányai átadási kötelezettségét. A házi őrizetben lévő személynek tilos közvetlen vagy közvetett kapcsolatba lépni a közrendet sértő cselekmények előkészítésével gyanúsított személyekkel.

A szükségállapot lehetôvé teszi olyan egyesületek vagy olyan tényleges csoportok feloszlatását, amelyek részt vesznek a közrendet súlyosan aláásó cselekmények elkövetésében, vagy elősegítik, illetve ösztönzik ezeket, és amelyek magukban foglalják a házi őrizetben lévő személyeket. Megszünt az 1955. április 3-i törvényben előírt sajtó- és rádióellenőrzés. A belügyminiszter betilthatja a terrorcselekmények elkövetésére buzdító vagy ezeket üdvözlő webhelyeket.

A belügyminiszter és a prefektusok felhatalmazást kapnak, hogy

- megtiltsák a felvonulásokat és a gyülekezést a közutakon (feltéve, hogy a közigazgatási hatóság a rendelkezésére álló eszközök alapján indokolja, hogy nem tudja biztosítani a biztonságukat);

— elrendeljék mindenféle helyiség ideiglenes bezárását, beleértve az előadótermek, ivóhelyek és gyülekezőhelyek bezárását, illetve „minden olyan vallási épületét, ahol olyan nyilatkozatokat tesznek, amelyek gyúlöletkeltésnek, erőszakos provokációnak vagy terrorcselekmények elkövetésére való felhívásnak vagy ezek dicsőítésének minősülnek";

— házkutatásokat rendeljenek el.

24 2015. november 20-i 2015-1501. sz. törvény a rendkívüli állapotról szóló, 1955. április 3-i 55-385. sz. törvény alkalmazásának kiterjesztéséről és rendelkezéseinek hatékonyságának megerősítéséről (Loi n² 2015-1501 du 20 novembre 2015 prorogeant l'application de la loi n ${ }^{\circ}$ 55-385 du 3 avril 1955 relative à l'état d'urgence et renforçant l'efficacité de ses dispositions). 
Semmilyen közigazgatási hatáskörben elrendelt házkutatás nem irányulhat olyan helyiségekre, amelyeket parlamenti mandátum gyakorlásához, illetve ügyvédek, bírók vagy újságírók szakmai tevékenységéhez rendeltek. Az államügyész tájékoztatást kap minden házkutatás elrendelésérőli; a kutatás rendôr jelenlétében történik.

A szükségállapot kihirdetése felhatalmazza a prefektust, hogy

- korlátozza az emberek vagy a jármúvek mozgását, és olyan védelmi vagy biztonsági övezeteket hozzon létre, ahol az emberek tartózkodása szabályozott;

— elrendeljen személyazonosság-ellenőrzést, szemrevételezést és poggyászátkutatást, valamint jármúellenőrzést.

Az alkotmányjogászok nagy része kritikusan fogadja a szükségállapot módozatait, vagy akár annak létét is. ${ }^{25}$ 2015-ben élénk vitákat kiváltó kísérlet történt arra, hogy ezt a jogintézményt az alkotmányban szabályozzák. A mellette szóló érv az volt, hogy végre egyértelmú, világos keretet lehetett volna adni e különleges jogrendnek. ${ }^{26} \mathrm{~A}$ fenntartások az ellenőrzések elégtelenségére és annak szükségességére vonatkoztak, hogy ezt az állítólagosan kivételes rendszert ne véglegesítsék. Végül a szükségállapot alkotmányba való beépítése elmaradt. Ezzel szemben az ország 2017-ben hivatalosan megszüntette a szükségállapotot, amelyben már majdnem két éve élt - ugyanakkor a szükségállapot fokozatosan beépült a normális jogrendbe. ${ }^{27} \mathrm{~A}$ 2017-ben elfogadott törvény ${ }^{28}$ négy olyan intézkedést vezetett be, amelyeket sokan aggályosnak tartanak az alkotmányosan garantált jogok és szabadságok tiszteletben tartása szempontjából:

— védelmi kerületek létrehozása;

— istentiszteleti helyek bezárása;

— egyedi adminisztratív ellenőrzési és felügyeleti intézkedések; valamint

- házkutatások.

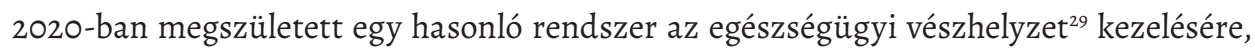
amelyet az alábbiakban tárgyalunk. Ezt megelőzően a miniszterelnök rendeletben szabályozta az utazást ${ }^{30}$ a kivételes körülmények elméletének szellemében.

25 Bővebben lásd: Cassia, 2016; Beaud-Guérin-Bargues, 2016; Rousseau, 2015.

26 Esplugas-Labatut, 2018.

27 Champeil-Desplats, 2017.

28 2017. október 30-i 2017-1510. sz. törvény a belső biztonság megerősítéséről és a terrorizmus elleni küzdelemról (Loi n²017-1510 du 30 octobre 2017 renforçant la sécurité intérieure et la lutte contre le terrorisme).

29 2020. március 23-i 2020-290. sz. törvény a Covid-19-járvány kezelésére (Loi n²020-290 du 23 mars 2020 d'urgence pour faire face à l'épidémie de Covid-19).

30 2020. március 16-i 2020-260. sz. rendelet az utazás szabályozásáról a Covid-19 vírus terjedése elleni küzdelem keretében (Décret n²020-260 du 16 mars 2020 portant réglementation des déplacements dans le cadre de la lutte contre la propagation du virus Covid-19). 


\subsection{A kivételes körülmények elmélete}

A kivételes körülmények lehetővé teszik a közigazgatási hatóság számára, hogy ne tartsa tiszteletben a szokásos törvényességet, feltéve, hogy

— bírói felügyelet alatt jár el;

— az események ezt megkövetelik;

- a közszolgáltatások folyamatosságát hivatott biztosítani.

A válsághelyzet okozta, a nemzet létfontosságú elemeit súlyosan veszélyeztető helyzet kezelésére az ítélkezési gyakorlat a „kivételes körülmények” elmélete révén olykor igen jelentős jogi kiigazításokat fogad el - ezeket a körülmények súlyossága teszi szükségessé. Bíróság határozta meg a „kivételes körülmények” alkalmazásának feltételeit az első világháború alatt hozott ítéletekben..$^{31} \mathrm{Az}$ Államtanács ezt követően elismerte a „kivételes körülmények” fennállását súlyos természeti katasztrófa esetén is. ${ }^{32} \mathrm{~A}$ közigazgatási hatóság minden esetben a szükség nevében szerez fontos hatásköröket, elsősorban a rendfenntartás területén, bár ez más közszolgáltatások múködését is érintheti, az alábbi két feltétel teljesülése esetén.

Egyrészt szükséges, hogy a körülmények valóban kivételes helyzetre vonatkozzanak, ami magában foglalja annak súlyosságát, rendellenességeit és kiszámíthatatlanságát (háborúk, zavargások vagy természeti katasztrófák esetén). Másrészt szükséges, hogy a körülmények elképzelhetetlenné tegyék a normális törvényesség tiszteletben tartását.

Törvényes kereteken kívül a hatáskör szabályai és a normahierarchia felborulnak: a végrehajtó hatalom olyan intézkedéseket hozhat meg, amelyek általában a törvényhozási, illetve az igazságügyi hatóság alá tartoznak, vagy de facto tisztviselők veszik át a hiányzó rendőri szervek helyét. A formai és eljárási szabályok alkalmazása felfüggeszthető. Ez a közigazgatás hatáskörének kivételes kiterjesztését eredményezi, mivel kivételes körülmények között a közigazgatási hatóságok rendkívül sürgős intézkedéseket tehetnek a pillanatnyi szükségletek kielégítése érdekében. Az időszak követelményeitől függően a szabadságjogokat olyan feltételekkel korlátozhatják, amelyek ilyen helyzet hiányában törvényellenesek vagy akár önkényesek.

Mindezek az intézkedések, határozatok sem esnek kívül a bírósági felülvizsgálat hatókörén, noha annak valódi hatálya kivételes válsághelyzetekben korlátozott. A bíró mindig alkalmazza a rendőri intézkedésekre az arányosság elvét. Az eltérést a bíró csak akkor engedélyezi, ha a különösen válságos körülmények között elérendő célok érdekében és a szabadságjogokba való beavatkozás mértékének arányában feltétlenül szükséges a megtett intézkedés - vagyis csak akkor, ha a jogtól való eltérés tökéletesen arányos a helyzettel. A bírói

31 CE 28 juin 1918, Heyriès, req. n 63412: az ügyre vonatkozó iratok előzetes közlése nélkül kimondott elbocsátásról; CE 28 févr. 1919, Dames Dol et Laurent, req. n 61593: az egyének szabad mozgását érintő rendőri intézkedésekről.

32 A Soufrière-vulkán kitörése Guadeloupe-ban (CE 18 mai 1983, Rodes, req. n² 25308). 
felülvizsgálat idővel fokozatosan erősödött, különösen az általános jogelvek elméletének az 1950-es évek elején történt fejlődésével. ${ }^{33}$

Anélkül, hogy önálló különleges jogrendet alkotna, a kivételes körülmények elmélete lehetôvé teszi a közigazgatási hatóságok bizonyos rugalmasságát a súlyos és előre nem látható körülményekre való reagálásban. Ezt az intézkedést az alapvető jogok tiszteletben tartásával hajtják végre, az utólagos bírói ellenőrzés mellett.

\section{Az alapjogok korlátozására vonatkozó szabályok különleges jogrend idején}

Tekintettel a rendkívüli elnöki jogkör széles körére, ezek a különleges jogrendben hozott intézkedések bármely alapvető jogot érinthetnek. Az ebből adódó jogsértések azonban elméleti jellegűek, mivel ezt a jogrendet már nem használják.

Az ostromállapot és a szükségállapot hasonló hatáskörre vonatkoznak, és ugyanazokat az alapvető jogokat érinthetik:

— a személy sérthetetlenségéhez és a magánlakás sérthetetlenségéhez füződő jog;

- a szabad mozgáshoz és a lakhatáshoz való jog;

— a gyülekezési jog és az üzleti tevékenység végzéséhez való jog.

Korábban a sajtószabadságot is korlátozni lehetett, a vonatkozó rendelkezéseket azonban azóta hatályon kívül helyezték.

Különösen tág a jogsértések területe, amelyet a bíró a kivételes körülmények elmélete nevében érvényesíthet. A múltban a bíróság ennek alapján indokolta meg a mozgásszabadság, valamint a tulajdonhoz való jog és a védelem jogának korlátozását.

$\mathrm{Az}$ alapjogokat különleges jogrend idején is garantálja az alkotmány. Idetartozik az 1789-es Emberi és polgári jogok nyilatkozata, az 1946-os alkotmány preambulumában biztosított jogok, valamint az ítélkezési gyakorlattal létrehozott jogok. E jogok tiszteletben tartását az Alkotmánytanács közvetett igénybevétele garantálja. A szabályok hierarchiájának megfelelően a közigazgatási bíró ellenőrzi bármely közigazgatási intézkedés jogszerűségét, beleértve a kormány vagy bármely helyi végrehajtó hatóság döntését. A bíró figyelembe veszi a különleges jogrend alkalmazását, és ellenőrzi, hogy az alapjogok korlátozása szükséges és arányos-e a kitûzött céllal (amely általában a közrend védelme).

33 Massot, 2013. 


\section{A koronavírus-járvány miatt bevezetett különleges jogrend Franciaországban}

\subsection{Az egészségügyi szülkségállapot}

Az egészségügyi szükségállapot ${ }^{34}$ olyan különleges jogrend, amelyet 2020-ban hoztak létre a Covid-19-járvány kezelésére. Ez a szükségállapotnak egy változata, amely meghatározott körülmények között alkalmazható „olyan egészségügyi katasztrófa esetén, amely jellegénél és súlyosságánál fogva veszélyezteti a lakosság egészségét”. ${ }^{35} \mathrm{Ez}$ a jogrend azonban ideiglenes: a közegészségügyi törvénykönyvbe ${ }^{36}$ ideiglenesen vezették be, és szükség esetén csak 2021. április 1-ig tartható fenn.

Amikor egy egészségügyi katasztrófa természeténél és súlyosságánál fogva veszélyezteti a lakosság egészségét, a Minisztertanács rendeletben (az egészségügyi miniszter jelentése alapján) dönt az egészségügyi szükségállapot kihirdetéséről. Ez a rendelet megindokolja és meghatározza azokat a területi körzeteket, amelyeken belül hatályba lép. A döntést motiváló (az egészségi helyzetról rendelkezésre álló) tudományos adatokat nyilvánosságra hozzák. A kormány haladéktalanul tájékoztatja a parlamentet az egészségügyi szükségállapotra vonatkozó intézkedésekről. Egy hónapon túl az egészségügyi szükségállapot meghoszszabbítását csak törvény engedélyezheti a Tudományos Tanáccsal ${ }^{37}$ folytatott konzultációt követően. A törvény meghatározza a meghosszabbítás időtartamát. Az egészségügyi szükségállapot azonban a jogszabályban meghatározott időtartam letelte elött minisztertanácsi rendelettel megszüntethetô.

A közegészségügyi törvénykönyv ${ }^{38}$ tíz olyan esetkört sorol fel, amelyben szabadságot korlátozó intézkedések hozhatók meg (kizárólag a közegészség garantálása céljából és olyan területeken, ahol egészségügyi szükségállapotot hirdettek ki). Ennek érdekében a miniszterelnök rendeletben (az egészségügyért felelős miniszter jelentése alapján) a következő intézkedéseket teheti:

— az emberek és a jármúvek mozgásának szabályozása vagy megtiltása, valamint a közlekedési eszközökhöz való hozzáférés és használatuk feltételeinek szabályozása;

- megtilthatja az embereknek, hogy elhagyják otthonukat, olyan utazás kivételével, amely családi vagy egészségügyi szükségletek tekintetében elengedhetetlen;

34 État d'urgence sanitaire.

35 2020. március 23-i 2020-290. sz. törvény a Covid-19 járvány kezelésére (Loi nº 2020-290 du 23 mars 2020 d'urgence pour faire face à l'épidémie de Covid-19).

36 Code de la santé publique (L. 3131-12 - L. 3131-20 cikk).

37 A Francia Köztársaság elnökének felkérésére a Covid-19 Tudományos Tanácsot (Conseil scientifique) 2020. március 11-én a szolidaritás és az egészségügy minisztere hozta létre, hogy tanácsot adjon a kormánynak a koronavírushoz kapcsolódó egészségi helyzet kezelésében.

38 Közegészségügyi törvénykönyv L. 3131-15. cikk. 
— elrendelheti az érintett személyek karanténját;

- elrendelheti az érintett személyek elkülönítését;

- a nyilvános és találkozóhelyek ideiglenes bezárásának elrendelése, biztosítva az emberek hozzáférését az alapvető árukhoz és szolgáltatásokhoz;

- a közutakon való összejövetelek, valamint bármilyen találkozók korlátozása vagy megtiltása;

— az egészségügyi katasztrófa elleni küzdelemhez szükséges összes áru és szolgáltatás igénybevétele;

— ideiglenes hatósági árszabályozást vezethet be olyan termékek esetében, amelyek bizonyos termékek piacán tapasztalt feszültségek megelőzéséhez és orvoslásához szükségesek;

— szükség esetén meghozhat minden olyan intézkedést, amely lehetővé teszi a betegek számára megfelelő gyógyszerek biztosítását, az egészségügyi katasztrófa elhárítását;

- szükség szerint rendelkezhet bármilyen más szabályozásról, amely korlátozza a vállalkozás szabadságát, kizárólag az említett egészségügyi katasztrófa elhárítása céljából.

A törvény előírja, hogy ezeknek az intézkedéseknek szigorúan arányosaknak kell lenniük a felmerülő egészségügyi kockázatokkal, és meg kell felelniük az adott helyen és időben uralkodó körülményeknek. Ha már nincs szükség rájuk, haladéktalanul meg kell szüntetni őket.

Az egészségügyi szükségállapotot 2020. március 24-től két hónapos időtartamra hirdették ki az ország egész területére. Ezt követően 2020. július 10-ig meghosszabbították. Az egészségügyi szükségállapotot 2020. október 17-től ismét rendeletben hirdették ki a Francia Köztársaság egész területére, majd 2021. február 16-ig meghosszabbították. Ez a kivételes rendszer lehetővé tette, hogy 2020 márciusától kezdve különféle eszközöket hozzanak létre a Covid-járvány elleni küzdelemben, például a kormány felhatalmazását arra, hogy többféle hatáskörben rendelettel fogadjon el jogszabályokat. A karantén ideje 2020. március 17-től május 11-ig tartott, a "kijárási tilalom” 21 és 6 óra között volt érvényes egyes országrészeken. Új országos karanténról döntöttek 2020. október 30-ával kezdődően.

\subsection{A koronavírus-járvány okozta rendkivüli állapot leküzdése érdekében bevezetett alapjog-korlátozás}

Amint azt a Velencei Bizottság 2020. október 8-i jelentésében megjegyezte, a Covid-19 elleni küzdelemmel kapcsolatos korlátozások a mozgás és a gyülekezés szabadsága mellett a vallásgyakorlás szabadságát és a magánélet tiszteletben tartásához való jogot is érintik egész Európában. ${ }^{39}$ Franciaországban 2020. május 18-án az Államtanács aránytalannak

39 Venice Commission, 2020, 15. o. 
nyilvánította az istentiszteleti helyek általános és abszolút bezárását. A 2020. szeptember 6-i ideiglenes határozatában pedig a nyilvános helyeken elő́rt kötelező maszkviseléssel foglalkozott a testület. Az Államtanács úgy határozott, hogy az arcmaszk viselése nagyobb földrajzi területre vonatkozóan is kötelezővé tehető annak érdekében, hogy a kötelezettség minden állampolgár részére egyértelmú legyen. Ehhez azonban igazolni kell az erősen fertőzésveszélyes gócok meglétét. ${ }^{40}$

A Velencei Bizottság jelentése megemlíti az Európában egyedülálló franciaországi esetet: az önkormányzati választások második fordulóját három hónappal elhalasztották, ami bizonyos hiányosságokat tárt fel a francia választási törvényben. Az Alkotmánytanács mindennek ellenére nem kifogásolta az első és a második szavazás közötti három hónapos különbséget. ${ }^{41}$

A Covid-19-válság "sajátos körülményeire” alapozva az Alkotmánytanács jóváhagyott egy sürgősségi törvényt ${ }^{42}$ annak ellenére, hogy azt az alkotmány 46. cikkét megsértve szavazták meg. Ez a cikk előírja, hogy tizenöt napnak kell eltelnie az organikus törvény első bevezetése és az első parlamenti vita között. Az organikus törvény felfüggesztette az Alkotmánytanács előzetes alkotmányossági felülvizsgálatának határidejét.

Franciaországban az elsőbbségi alkotmányossági kérdést, ${ }^{43}$ amelyben a peres fél megtámadhatja a saját jogesetére vonatkozó törvény alkotmányosságát, a bíróság a Semmítőszékhez vagy az Államtanácshoz továbbítja. Amennyiben jogos a kérdés, ezt az Államtanács vagy a Semmítőszék az Alkotmánytanács elé terjeszti. Ezt az előzetes ellenőrzést három hónapon belül be kell fejezni, ennek hiányában a kérést közvetlenül továbbítják az Alkotmánytanácsnak, amelynek három hónapon belül döntést kell hoznia. ${ }^{44} \mathrm{~A}$ bíróságok (járvány miatt) várható bezárásával az Alkotmánytanács tagjai azzal a lehetőséggel szembesültek, hogy gyengén indokolt kérelmek sokasága halmozódik fel az asztalukon. A parlament ezért sürgősségi törvényt fogadott el, amely felfüggesztette a kérdés Alkotmánytanácshoz történő továbbításának határidejét. ${ }^{45}$ Noha kétségtelenül érintette a polgárok tisztességes és gyors tárgyaláshoz való jogát, az ilyen eseti és ideiglenes intézkedés hatása korlátozott maradt. A jogszabályok elfogadásának módja, valamint az Alkotmánytanács érvelése azonban aggodalmat keltett az alkotmányjogászok körében. ${ }^{46}$

$\mathrm{Az}$ ország legfőbb politikai és igazságszolgáltatási szerveinek müködésében bármilyen módosításnak - ahogyan ez itt az Alkotmánytanács esetében történt - organikus

40 Venice Commission, 2020, 24. o.

41 Venice Commission, 2020, 27. o.

42 Conseil Constitutionnel, décision n 2020-799 DC du 26 mars 2020, Loi organique d'urgence pour faire face à l'épidémie de Covid-19.

43 Alkotmány 61-1. cikk (ez hozzávetőlegesen a magyar alkotmányjogi panasznak felel meg).

44 2009. december 10-i 2009-1523. sz. organikus törvény az Alkotmány 61-1. cikk alkalmazásáról (Loi organique n 2009-1523 du 10 décembre 2009 relative à l'application de l'article 61-1 de la Constitution).

45 2020. március 30-i 2020-365. sz. organikus törvény a Covid-19-járvány kezelésére (Loi organique n²020-365

du 30 mars 2020 d'urgence pour faire face à l'épidémie de Covid-19, JORF n0078 30/03/2020).

46 Gicquel, 2020; Benzina, 2020. 
törvény formájában kell történnie. ${ }^{47} \mathrm{Az}$ alkotmány elöírja, hogy egy organikus törvényjavaslat a benyújtás napjától számított legalább hat hét elteltével megvitatásra kerül, először a parlamentben.

Az időszak legalább hat hétig tart, ha a szokásos eljárást követik, illetve a gyorsított eljárás alkalmazása esetén ${ }^{48}$ a törvény benyújtását követő tizenöt napos időszak lejártáig. A kormány az utóbbi, rövidített időszakot választotta. Az alkotmány azonban még rendkívüli körülmények között sem kínál lehetőséget ennek a tizenöt napos időszaknak a csökkentésére. Az organikus törvényt ennek ellenére huszonnégy órán belül elfogadták a benyújtása után. Az alkotmány azt is előírja, hogy „az organikus törvényeket csak akkor lehet kihirdetni, ha az Alkotmánytanács kinyilvánította az alkotmánynak való megfelelést”. ${ }^{49}$

Az Alkotmánytanács tehát két kockázatos javaslattal nézett szembe:

- vagy a pragmatikus megközelítést követve, azonnali érdekének megfelelően megalkotott intézményi törvényt érvényesítsen, nyilvánvalóan megsértve ezzel az alkotmány formai rendelkezéseit;

— vagy pusztán formai okokból ítéljen el olyan törvényt, amelynek tartalma szinte semmilyen ellenzést nem váltott ki.

Az Alkotmánytanács az előbbi megoldás mellett döntött.

A francia bíróságok döntéseit a tömörség hagyománya jellemzi. Azokban a ritka esetekben azonban, amikor szükségesnek tartják a törvény kifejezett rendelkezése elleni döntést, rendkívül fontos, hogy a bíró ezt kellően megindokolja:

— vagy minimalizálja a kivétel súlyosságát azáltal, hogy összekapcsolja egy bevett ítélkezési gyakorlattal;

— vagy alaposan elmagyarázza azokat a nagyon sajátos körülményeket, amelyek ilyen rendkívüli jogsértéshez vezettek.

Határozatában a francia Alkotmánytanács egyiket sem tette meg. Ehelyett a „jelenlegi körülményekre" hivatkozva (amelyek láthatólag különböztek a közigazgatási bíróságok által alkalmazott százéves "kivételes körülmények elméletétől”) ${ }^{50}$ úgy ítélte meg, hogy - az említett körülmények miatt - „nincs szükség” megítélni, hogy az eljárás ellentétes az Alkotmánnyal.

Noha az organikus törvény potenciálisan késleltette a peres felek hozzáférését az Alkotmánytanácshoz, mégis rendelkezett egy „megszüntetési záradékkal”, amely 2020.

47 Az alkotmány 46. cikkében meghatározott külön eljárást követve, a szokásos törvényekénél magasabb fokú formalitással.

48 Alkotmány 45. cikk.

49 Alkotmány 45. cikk.

50 Champeil-Desplats, 2020. 
június 30-tól lépett hatályba. Önmagában az Alkotmánytanács határozatának alig volt más azonnali hatása, mint az, hogy lehetôvé tette az Alkotmánytanácshoz való hozzáférés késleltetését. Az eset nem jelenti a joghatóság hirtelen megváltozását, mivel az eljárás kérdésére összpontosított. Például egy nemrégiben hozott (a terrorizmushoz kapcsolódó bûncselekmények miatt elítélt volt foglyokról szóló törvényt megsemmisítő) ${ }^{51}$ itélet azt jelzi, hogy az Alkotmánytanács továbbra is az emberi jogok és a jogállamiság fenntartását kívánja megvalósítani. Összességében az Alkotmánytanács döntését az eljárási kérdések iránti engedékenység mutatójaként elemezték..$^{52}$ Megkérdőjelezték ennek az engedékenységnek a célszerüségét: bár a Covid-19-járvány minden bizonnyal vészhelyzetnek minősül, ebben a konkrét esetben semmi sem akadályozta a tizenöt napos időszak alkalmazását. Még az Alkotmánytanács döntéseinek esetleges késedelme sem okozott volna jogi következményt.

A határozatot a strukturált érvelés hiánya miatt is erősen bírálták:53 nem mutatott logikus következetességet az engedékenység tekintetében, mivel a bírók nem határoztak meg egyértelmú feltételeket, amelyek alapján a jövőben hasonló helyzetet hasonló módon lehet majd elbírálni. Talán ennél is fontosabb, hogy az eljárásnak, különösen az alkotmányos kérdésekben, mindig komoly jelentősége van. Alapvető érdeme, hogy megakadályozza az intézményi mechanizmusok elhamarkodott módosítását, például abban az esetben, ha egy autoriter hatalom a demokratikus intézmények csorbítására kívánna felhasználni egy vészhelyzetet. Ebben az értelemben az Alkotmánytanács döntése a célszerúséget választotta az egységesség helyett. Szerencsétlen precedenst teremtett azáltal, hogy ajtót nyitott az alkotmányos norma megsértésének, legalábbis annak alaki rendelkezéseiben. Jelen helyzetben a demokratikus intézmények szilárdsága sikertelen tesztjeként értékelhetjük - vészhelyzetben, éppen akkor, amikor szerepüknek meghatározóbbnak kell lenni, mint valaha. ${ }^{54}$ Tekintettel arra, hogy sem felülvizsgálat, sem fellebbezés tárgya nem lehet, ez a határozat az Alkotmánytanács politikai jellegére emlékeztet az igazságszolgáltatáson felül. Bár a jogszabályoknak az a szerepük, hogy a szabályokat a körülmények változásához igazítsák, az Alkotmánytanácsnak a politikai választások döntnökeként való fellépése árnyékot vethet Franciaország jogállamiságára. ${ }^{55}$

\section{A különleges jogrend kihirdetésének gyakorlati esetei}

Az ostromállapot első alkalmazásai Franciaországban a belső zavargások és a forradalmak elhárítására irányultak 1848-ban, 1849-ben, de 1871-ben, a párizsi kommün alatt is

51 Decision n 2020-805 DC, 7 août 2020, Loi instaurant des mesures de sûreté à l'encontre des auteurs d'infractions terroristes à l'issue de leur peine.

52 Jeanneney, 2020.

53 Gicquel, 2020; Benzina, 2020; Jeanneney, 2020.

54 Derosier-Cartier, 2020.

55 Jacquin, 2020. 
bevezették. Az ostromállapotot a két világháború során hirdették ki, az V. köztársaság alatt azonban soha.

A rendkívüli elnöki jogkör egyetlen alkalmazása 1961. április 23. és 1961. szeptember 30. között, szintén hat hónapig tartott, holott az úgynevezett tábornokok algériai puccsa három nap alatt megbukott. Noha az alkalmazásához szükséges körülmények találkozása vita tárgyát képezi, az Alkotmánytanács hozzájárulása biztosítja a törvényesség tiszteletben tartását. ${ }^{56}$ Mindazonáltal arra is rá kell mutatni, hogy 15 évvel később ugyanezen Alkotmánytanács elnöke megerősítette, hogy a puccs leverése után „jogi szempontból kétségtelen”, hogy „a 16. cikk szerinti rendszer fenntartása ellentétes volt e szöveg szellemével és betújével egyaránt". ${ }^{77}$ Tekintettel arra, hogy közel 60 évig nem volt példa az alkalmazására, a rendkívüli elnöki jogkör pontos mértéke továbbra is bizonytalan, különös tekintettel az Alkotmánytanács szerepének azóta történt jelentős kiterjesztésére. ${ }^{58}$

A szükségállapotot 1955 és 2015 között hatszor alkalmazták. A szükségállapotot az algériai háború idején, az 1984-es események során Új-Kaledóniában, a 2005. októberi városi zavargások és a 2015. novemberi terrortámadások után vezették be. Az algériai háború idején a szükségállapot indokolta a szabad mozgás és a sajtószabadság korlátozását. A 2015. novemberi párizsi és saint-denis-i támadásokat követően szükségállapotot vezettek be, majd három hónappal meghosszabbították azt. A 2016. júliusi nizzai terrortámadás a szükségállapot hat hónappal történő meghosszabbítását eredményezte. Ezt követően kétszer hosszabbították meg 2017. november 1-ig. Ez azt mutatja, hogy a szükségállapot jelentős időtartamra meghosszabbítható, amennyiben azt a parlament rendszeresen jóváhagyja és határidőhöz köti. ${ }^{59}$

A kivételes körülmények elméletét főként a két világháború alatt, valamint közvetlenül a háború utáni időszak összefüggésében használták. Használata a fent említett különleges jogrendek kialakulásával ritkábbá vált. A közigazgatási hatóság sikertelenül hivatkozott a kivételes körülményekre az 1968. májusi események nyomán, ${ }^{60}$ valamint egy ciklon pusztítása után Guadeloupe-ban. ${ }^{61} \mathrm{~A}$ kivételes körülmények elméletének legutóbbi, 1989-es alkalmazása az új-kaledóniai zavargásokhoz kapcsolódik. ${ }^{62} \mathrm{Az}$ ítélkezési gyakorlat szigorú feltételeket támaszt a kivételes körülmények fennállásának elismerésével szemben. Feltételezi a közrend elleni támadást, amely lehetetlenné teszi a közhatalmak normál múködését.

56 Lásd az Alkotmánytanács 1961. április 23-i, 61-1 AR16 sz. döntését: www.conseil-constitutionnel.fr/ decision/1961/611AR16.htm (Letöltve: 2020. november 18.).

57 Noël, 1976, 155. o.

58 Lásd az Alkotmánytanács 1971. július 16-i, 71-44 DC sz. döntését: www.conseil-constitutionnel.fr/ decision/1971/7144DC.htm (Letöltve: 2020. november 18.).

59 Baranger, 2016, 453. o.

60 CE 12 juillet 1969, Chambre de commerce de Saint-Étienne, req. $n^{\circ} 76089$.

61 TC 22 juin 1998, req. $n^{\circ}$ 98-03.105.

62 CE 3 nov. 1989, req. n 66118 (egy önkormányzati tanács feloszlatásáról). 


\section{5. Összegzés}

Az alábbi táblázat összefoglalja a francia különleges jogrendi szabályozással kapcsolatos legfontosabb rendelkezéseket:

\begin{tabular}{|c|c|c|c|c|}
\hline & $\begin{array}{l}\text { Rendkívüli elnöki } \\
\text { intézkedési jogkör }\end{array}$ & Ostromállapot & Szülkségállapot & Kivételes körülmények \\
\hline $\begin{array}{c}\text { Szabályozás } \\
\text { szintje }\end{array}$ & \multicolumn{2}{|c|}{ alkotmányos } & törvényes & bírósági gyakorlat \\
\hline $\begin{array}{c}\text { Elrendelési } \\
\text { okok }\end{array}$ & $\begin{array}{l}\text { Súlyos és közvetlen } \\
\text { veszély fenyegeti: } \\
\text { — a köztársaság } \\
\text { intézményeit; } \\
\text { — a nemzet } \\
\text { függetlenségét } \\
\text { vagy területi } \\
\text { integritását; } \\
\text { — az ország nem- } \\
\text { zetközi kötele- } \\
\text { zettségvállalásai } \\
\text { teljesítését. }\end{array}$ & $\begin{array}{l}\text { — Külföldi } \\
\text { háború; } \\
\text { — fegyveres } \\
\text { felkelés; } \\
\text { — közvetlenül } \\
\text { fenyegető } \\
\text { veszély. }\end{array}$ & $\begin{array}{l}\text { - A közrend } \\
\text { súlyos meg- } \\
\text { sértésének } \\
\text { közvetlen } \\
\text { veszélye; } \\
\text { — közveszély } \\
\text { előidézésére } \\
\text { alkalmas } \\
\text { események } \\
\text { megtörténte } \\
\text { esetén. }\end{array}$ & $\begin{array}{l}\text { Súlyos, rendellenes } \\
\text { és kiszámíthatatlan } \\
\text { helyzet, amely elkép- } \\
\text { zelhetetlenné teszi } \\
\text { a normális törvényesség } \\
\text { tiszteletben tartását. }\end{array}$ \\
\hline Elrendelés & $\begin{array}{c}\text { Az elnök által, } \\
\text { miután egyeztetett } \\
\text { a miniszterelnökkel, } \\
\text { a parlament két } \\
\text { házának elnökével } \\
\text { és az Alkotmányta- } \\
\text { náccsal. }\end{array}$ & \multicolumn{2}{|c|}{$\begin{array}{l}\text { A Minisztertanács által, } 12 \text { napon túli } \\
\text { meghosszabbításáról kizárólag } \\
\text { a parlament dönthet. }\end{array}$} & $\begin{array}{l}\text { Fennállását a bíróságok } \\
\text { utólag állapítják meg, } \\
\text { eljárás során. }\end{array}$ \\
\hline $\begin{array}{l}\text { Felhatal- } \\
\text { mazott }\end{array}$ & elnök & $\begin{array}{l}\text { katonai } \\
\text { hatóságok }\end{array}$ & polgári hatóságok & közigazgatási hatóságok \\
\hline $\begin{array}{c}\text { Gyakorlati } \\
\text { esetek }\end{array}$ & $\begin{array}{c}\text { 1961. április 23. - } \\
\text { 1961. szeptember } 30 .\end{array}$ & $\begin{array}{l}\text { a II. világ- } \\
\text { háború óta nem } \\
\text { alkalmazott }\end{array}$ & \multicolumn{2}{|c|}{ Lásd a fejezet 1.3. és 1.4. pontját } \\
\hline
\end{tabular}

9. táblázat

Franciaország különleges jogrendi szabályozásának összefoglalása

Forrás: a szerző saját szerkesztése

A francia különleges jogrendszer sokrétû és részben elavult. Sokrétû, mivel az alkotmánnyal, a törvényekkel, de a joggyakorlattal kapcsolatos előírások is szabályozzák. 
Az alkotmányi szintû́ jogrendeket ma már nem alkalmazzák: inkább a meglévő törvényi szintû́ rendelkezéseket, illetve új ad hoc törvények létrehozását részesítik előnyben. Így az alapvető jogok megsértése, amelyet az utóbbi években elítéltek Franciaországban, inkább a rendes jogrendi törvények alkalmazásából fakad, mintsem egy különleges jogrend alkalmazásából. Az alkotmányban meglévő rendkívüli elnöki intézkedési jogkört és ostromállapotot már nem alkalmazzák. A jelenlegi válságok kezelésére a kormány elsősorban a szükségállapotot alkalmazza, amelyet egy 1955-ös törvény hozott létre, és amelyet a „kivételes körülmények" esetjogi elmélete kiegészít. Az V. köztársaság olyan rendszer, amelyben a mérleg nyelve a hatalom szétválasztása során a végrehajtó hatalmi ág felé hajlik. A végrehajtó hatalom lényegében döntéshozó, míg a jogalkotó hatalmat tanácskozó testületek alkotják. Következésképpen a különleges jogrendek alkalmazása a végrehajtó hatalom hatásköreinek fokozottabb koncentrációjához vezet; ez az intézményrendszer jellegére való tekintettel feleslegesnek vagy akár károsnak is tekinthető. Az elnök személyében megtestesülő végrehajtó hatalmat - helyesen vagy helytelenül - egyedüli döntéshozónak és ezért a válság kezeléséért egyedüli felelősnek tekintik.

A magyar Alaptörvény kilencedik módosítása az észszerúsítés és az egyszerűsítés céljából gyökeresen átalakítja a különleges jogrendre vonatkozó szabályozást. Ezzel megszüntet néhány alkalmi rendelkezést, például a „terrorveszélyhelyzetet”, amely egyértelmúen a 20152016-os franciaországi terrortámadások nyomán jött létre. Franciaországban egy hasonló reform nem lenne haszontalan, azonban néhány akadály áll az útjában: először is, a jelen politikai tényezôk megnehezítik az alkotmánymódosítást. Az alkotmány módosításához a parlament háromötödös többsége szükséges, vagy alternatív megoldásként a népszavazás kockázatos gyakorlatához lehetne folyamodni. Ezenkívül a francia alkotmánytörténet azt mutatja, hogy az intézményi gyakorlatot a mindenkori követelményekhez igazítják, az alkotmányt ritkábban módosítják azért, hogy a gyakorlathoz igazodjon. Ezért a különleges jogrendek teljes átalakítása a közeljövőben nem valószínú. Franciaországban 1970 óta nem került szóba a különleges jogrendszer komolyabb átalakítása. Az a terv azért volt sikertelen, mert hasznosságát elégtelennek tartották, és az akkori turbulens politikai helyzetben nyugtalanságot kelthetett volna. Mindenesetre nem túnik szükségesnek a végrehajtó hatalom megerősítése, amely az V. köztársaság rendszerében amúgy is túlsúlyban van. Az eljövendő magyar jogrendben a hadiállapot megfelelője a francia jogrendben az ostromállapot lenne, amely fegyveres konfliktust jelent az ország területén. A francia rugalmas szükségállapot mind a veszélyhelyzetnek, mind a szükségállapotnak megfelel, bár utóbbi esetben az események súlyossága elvben a rendkívüli elnöki jogkör alkalmazását igazolhatná.

A koronavírus-járványhoz kapcsolódó válság láthatóvá tette a meglévő mechanizmusok elégtelenségét, hiszen szükségesnek találták egy új, bár elvileg ideiglenes különleges jogrend megvalósítását, azaz az egészségügyi szükségállapotot. Az ez alkalomból létrehozott egész- 
ségvédelmi tanács átláthatatlansága és a döntések központosítása kritika tárgyát képezi. ${ }^{63}$ A hosszú távú egészségügyi sürgősségi kezelési rend létrehozásáról szóló törvényjavaslat, amelyet a minisztertanács elé terjesztettek 2020 végén, összehasonlítható a veszélyhelyzet megszúnésével összefüggő átmeneti szabályokról és a járványügyi készültségről szóló 2020. évi LVIII. törvénnyel, amennyiben ez a különleges jogrend alapvető jellemzőinek a normális jogrendbe beépítését eredményezi: nevezetesen a kormány felhatalmazását bizonyos szabadságok gyakorlásának korlátozására anélkül, hogy előzetesen konzultálna a parlamenttel. Hasonlóképpen megkülönbözteti az egészségügyi válsághelyzetet és az egészségügyi vészhelyzetet (vagy a francia kifejezés szerinti szükségállapotot).

Összehasonlító szempontból az alapvető jogok tiszteletben tartása és a hatalom szétválasztásának tiszteletben tartása kétféle módon biztosított. Egyrészt a kormánynak rendszeres időközönként konzultálnia kell a parlamenttel, a törvény meghatározza a kormányra bízott hatásköröket, és szisztematikusan határidőt ír elő. Emlékszünk arra, hogy a magyar esetben mindenekelőtt a határidő hiánya okozott nehézségeket. A francia parlament külön vizsgálóbizottságokat is létrehozott a vészhelyzet kezelése érdekében. ${ }^{64}$ Másrészt a kormány fellépése továbbra is bírói ellenőrzés alatt áll. A közigazgatási bíró megvizsgálja a végrehajtó hatalom intézkedéseinek jogszerűségét. Az Alkotmánytanács, amelynek hatásköre az 1970-es évek óta folyamatosan nőtt, ma kiemelt szerepet játszik az alapvető jogok és szabadságok védelmében. Ebből a szempontból a magyar eset fordított tendenciát mutat, az alkotmánybíróság szerepének korlátozása felé a parlamenti szuverenitás javára - a parlament mozgástere azonban korlátozottnak túnik a végrehajtó hatalom tekintetében, mivel a Kormány nagy többséggel rendelkezik, ami megkönnyíti a fegyelmet a parlamenti csoporton belül.

\section{Irodalomjegyzék}

Agamben, G. (2005) State of Exception. Chicago: University of Chicago Press

BARANGER, D. (2016) 'Létat d'urgence dans la durée', Revue française de droit administratif, 32(3), 447-454. o.

Beaud, O., Guérin-Bargues, C. (2016) L'état d'urgence. Étude constitutionnelle, historique et critique. 1. kiadás. Paris: LGDJ

Benzina, S. (2020) La curieuse suspension des délais d'examen des questions prioritaires de constitutionnalité [Online]. Elérhetô: http://blog.juspoliticum.com/2020/04/03/la-curieusesuspension-des-delais-dexamen-des-questions-prioritaires-de-constitutionnalite-parsamy-benzina\%e2\%80\%a8/ (Letöltve: 2020. november 18.)

63 Hirsch, 2021; Blondiaux, 2021.

64 Venice Commission, 2020, 19. o. 
Blondiaux, L. (2021) 'De la démocratie en France. En finir avec les faux-semblants', Esprit, 2021/4, 87-99. 0.

Cassia, P. (2016) Contre l'état d'urgence. 1. kiadás. Paris: Dalloz

Champeil-Desplats, V. (2017) 'Histoire de lumières françaises: l'état d'urgence ou comment l'exception se fond dans le droit commun sans révision constitutionnelle', Revue interdisciplinaire d'études juridiques, 79(2), 205-227. o.

Champeil-Desplats, V. (2020) 'Le Conseil constitutionnel face à lui-même', La Revue des droits de l'homme [Online]. Elérhető: https://journals.openedition.org/revdh/9029 (Letöltve: 2020. december 10.)

Derosier, J.-P., CARTIER, E., (2020) 'Chronique de droits fondamentaux et libertés publiques (janvier 2020 à juin 2020)', La sécurité juridique, 5(7), 99-111. o.

Esplugas-Labatut, P. (2018) 'Pour la constitutionnalisation de l'état d'urgence', Revue française de droit constitutionnel, 2018/3, 485-496. 0.

GARrigou, A. (2017) La politique en France: De 1940 à nos jours. 1. kiadás. Paris: La Découverte

Gicquel, J.-E. (2020) 'La loi organique Covid-19 et l'irrespect non sanctionné de la Constitution', Gazette du Palais, 2020/14, 27-29. o.

Hirsch, E. (2021) Une démocratie confinée: L'éthique quoi qu'il en coûte. 1. kiadás. Toulouse: Érès JACQUIN, J.-B. (2020) Coronavirus: L'état d'urgence sanitaire ouvre des brèches dans l'État de droit [Online]. Elérhető: www.lemonde.fr/societe/article/2020/03/28/coronavirus-l-etat-durgence-sanitaire-ouvre-des-breches-dans-1-etat-de-droit_6034751_3224.html (Letöltve: 2020. december 15.)

JEANNENEY, J. (2020) 'La non-théorie des «circonstances particulières»', Droit administratif, 76(15), 843-847. 0 .

Manin, B. (2015) Le paradigme de l'exception [Online]. Elérhető: https://laviedesidees.fr/Leparadigme-de-l-exception.html (Letöltve: 2020 . november 18.)

Massot, J. (2013) 'Le Conseil d'État face aux circonstances exceptionnelles', Les Cahiers de la Justice, 2013/2, 27-39. o.

NoËL, L. (1976) De Gaulle et les débuts de la Ve République. 1. kiadás. Paris: Plon

Pierré-CAPS, S. (2016) 'Constitutionnaliser l'état d'urgence?', Civitas Europa, 2016/1, 141-154. o.

Platon, S. (2008) 'Vider l'article 16 de son venin: les pleins pouvoirs sont-ils solubles dans l'état de droit contemporain?', Revue française de droit constitutionnel, 2008/5, 97-116. o.

ROUSSEAU, D. (2015) Un projet de révision constitutionnelle recevable mais qui doit être réécrit [Online]. Elérhető: www.lemonde.fr/idees/article/2015/12/21/un-projet-de-revision-constitutionnellerecevable-mais-qui-doit-etre-reecrit_4835966_3232.html (Letöltve: 2020. december 15.)

SÁGVÁRI, Á. (2017) 'Különleges jogrend a francia jogban', Iustum Aequum Salutare, 13(4), 179188. 0.

SAINT-BONNET, F. (2008) 'L'état d'exception et la qualification juridique', Cahiers de la recherche en droits fondamentaux, 2008/6, 29-38. 0. 
SIRINELLI, J.-F. (főszerk.) (1995) Dictionnaire historique de la vie politique au XXe siècle. 1. kiadás. Paris: PUF

Venice Commission (2020) Interim Report on the Measures Taken in the EU Member States as a Result of the COVID-19 Crisis and Their Impact on Democracy, the Rule of Law and Fundamental Rights (Study No. 995/2020) [Online]. Elérhető: www.venice.coe.int/webforms/documents/?pdf=CDL$\mathrm{AD}$ (2020)018-e (Letöltve: 2020. december 15.) 